\title{
Tracing of haematotoxic agents in water with the aid of captive fish: a study with captive adult Atlantic salmon Salmo salar in the River Don, Aberdeenshire, Scotland
}

\author{
N. C. Everall* , C. G. Mitchell, D. B. Groman, J. A. A. Johnston \\ North East River Purfication Board, Greyhope House, Greyhope Road, Torry, Aberdeen AB1 3RD, United Kingdom
}

\begin{abstract}
The riverine location of haematotoxic discharges was determined by exposing adult captive Atlantic salmon (Salmo salar L.) to River Don water in situ. Experiments were conducted using a control group and 4 test groups at different distances downstream of a paper mill and field drain discharges. Significant changes in whole blood haemoglobin, plasma cholesterol and bilirubin in salmon from polluted sites indicated the induction of a marked bilirubinaemia in test fish. The most marked pathology occurred in salmon exposed at a site below all the major effluent inputs into the river and suggested additive/synergistic effects between discharges. Pathophysiological changes in captive test fish from the polluted area closely resembled those recorded in wild Don salmon suffering from a non-infectious hyperbilirubinaemia. The effluent cause of the pigmented salmon syndrome in wild Don salmon appeared to be located between the reference site and a point $14 \mathrm{~km}$ downstream in the River Don.
\end{abstract}

\section{INTRODUCTION}

The River Don, Aberdeenshire, comprises the sixth most extensive river system in Scotland and supports a modest Atlantic salmon, sea trout and resident brown trout fishery. However, unlike other Scottish rivers of similar size and resource the River Don is unique in both the scope of industrial exploitation and the extent of urban accessibility. Consequently the Don fisheries have in recent times experienced a diversity of manmade pressures on both rearing habitat and returning adult salmon. A major problem has been annual epidemics of a pollutant-related haemolytic anaemia in both spring and autumn run adult salmon in the Don fishery. In recent years literally hundreds of adult salmon deaths have been attributed to this condition. Results from the screening of test and wild Don salmon with the haemolytic syndrome for infectious agents have been negative (Groman et al. 1989). The

\footnotetext{
- Present address: Severn-Trent Water Ltd, PO Box 51, Raynesway, Derby DE2 7 JA, UK
}

pathophysiological condition of the adult wild Atlantic salmon suffering from the haemolytic syndrome has been well documented (Groman \& Miller 1987). However, the causative raw effluents have not been hitherto identified.

This paper describes the results of ecotoxicological investigations for characterising sections of a river with captive adult Atlantic salmon of wild origin as the test species. The use of adult salmon (ca 3.5 to $4 \mathrm{~kg}$ ) was numerically limiting due to their water quality requirements and difficulty of capture but more pertinent than using other test animals. Similar tests using larger numbers of rainbow trout or farmed salmon had previously failed to elicit significant physiological disturbances of a haemolytic nature (Groman et al. 1989). Further studies had been unsuccessful in isolating the riverine sources of potential haemolytic agents. Earlier experiments with prespawning adult salmon from the River North Esk had successfully reproduced the clinical haemolytic anaemia observed in wild Don salmon at Site E on the River Don (Groman et al. 1989) as shown in Fig. 1.

A diagramatic representation of the research area is given in Fig. 1. Downstream from Site A (control) major 


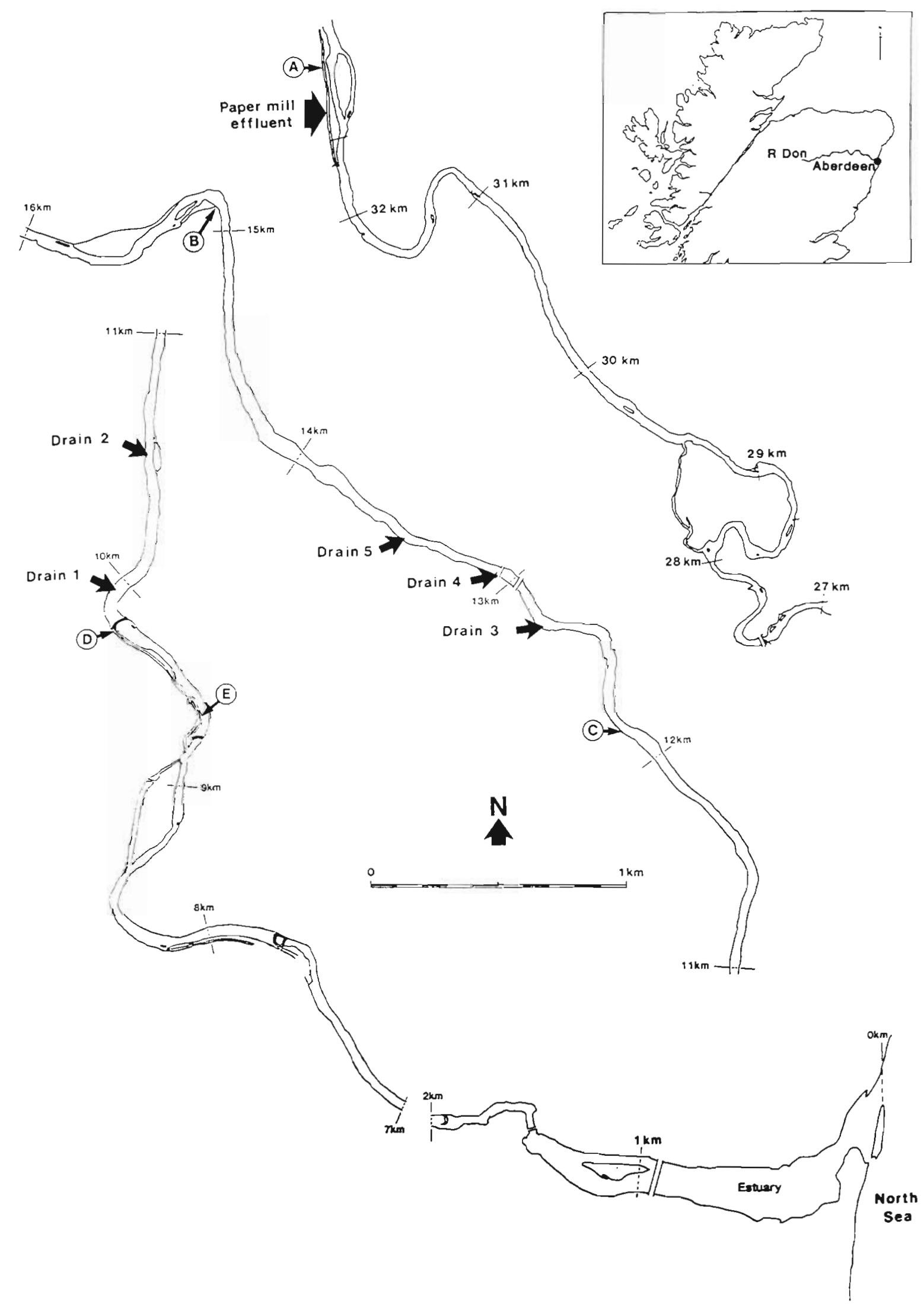

Fig. 1 The research area in Scotland. Fish tank Sites A (reference) to E and points of major effluent discharge into the recipient are shown. Distance from the estuary is marked in kilometres. Weirs are indicated at $7.7,9.2$ and $9.8 \mathrm{~km}$ 
discharges into the river include a continuous flow of 70 to $80 \mathrm{l} \mathrm{s}^{-1}$ of raw paper mill effluent between Sites A and $B$. Five field drains of variable flow containing effluent from a variety of industrial concerns including an airport (Gay et al. 1987) enter the river between Sites $B$ and $E$. Three of the field drain effluents enter the river between Sites B and C with the remaining 2 discharging to the river between Sites $C$ and $D$.

In the present study we held small numbers of adult salmon in large fish tanks at discrete riverine locations. The fish were supplied with a continuous flow of adjacent river water and the chosen reference Site $A$ had historically never produced significant physiological disturbances in captive salmon or rainbow trout (Groman et al. 1989).

\section{MATERIALS AND METHODS}

Adult wild Atlantic salmon (fork length 68 to $82 \mathrm{~cm}, 3$ to $5 \mathrm{~kg}$ ) were obtained via commercial netsmen from the River North Esk in Kincardinshire. One third of the test fish were transported to the Marine Laboratory in Aberdeen where groups of 2 were held for $3 \mathrm{~d}$ in ca $500 \mathrm{l}$ darkened fibreglass tanks with a continuous flow of carbon-filtered tap water at 5 to $8{ }^{\circ} \mathrm{C}$. On the third day, $5 \mathrm{ml}$ of blood was taken from the fish under anaesthesia (benzocaine) by caudal venipuncture using $5 \mathrm{ml}$ syringes and 18 gauge needles both heparinised with a 300 unit $\mathrm{ml}^{-1}$ solution of sodium heparin. All blood samples were placed in lithium heparinised vacutainers, thoroughly mixed and maintained at $4{ }^{\circ} \mathrm{C}$ prior to haematological determinations.

Following this prebleeding these and the remaining fish from the North Esk were transferred to tanks on the River Don where they were distributed between Sites A (reference), B, C, D and E. From a total of 12 prespawned experimental salmon, 10 were females with 2 males, held one at Sites D and E respectively. A maximum of only 3 adult wild Atlantic salmon could be successfully held at a given site during the test period of mid March to mid May in 1988 due to their size and high water quality demands. The fish were maintained in $4 \mathrm{~m}^{3}$ fibreglass field tanks which received ca $15 \mathrm{l}$ $\min ^{-1}$ of adjacent river water.

After 2 to $3 \mathrm{wk}$ on the river the fish were killed and bled as described above. The majority of blood parameter measurements and plasma extractions were completed in the field at $4{ }^{\circ} \mathrm{C}$ but following transport on ice the fish were then further autopsied in the laboratory. Livers were excised in situ, maintained at 4 or $-80^{\circ} \mathrm{C}$ and immediately stored at $-80^{\circ} \mathrm{C}$ in the laboratory prior to analyses of xenobiotic detoxification enzymes by Drs S. George and M. Lever at Stirling University.
Haematocrit was calculated in the field using 3 replicates on a minicentrifuge and osmotic fragility of red blood cells was determined by the method of Hughes \& Martinez (1986). Osmotic fragility measurements incorporated additional $0.1 \%$ and $0.65 \% \mathrm{NaCl}$ solutions which had been previously determined for adult salmon blood. Live total blood cell counts and mean erythrocyte volumes were determined within 1 to $4 \mathrm{~h}$ of sample collection using a Coulter Counter Model ZM and Channelyser C256. Cell counts $\left(\times 10^{6} \mathrm{~mm}^{-3}\right)$ were determined from triplicate samples with $10 \mu \mathrm{l}$ of whole blood added to $4.99 \mathrm{ml}$ of sterile filtered $(0.45 \mu \mathrm{m})$ Cortland saline in a sterilin bijoux maintained at $4^{\circ} \mathrm{C}$.

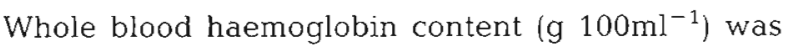
determined according to the quantitative colourimetric cyanmethaemoglobin assay (Blaxhall \& Daisley 1973). Calibration curves were prepared using a Sigma haemoglobin standard and results were expressed as the mean of triplicate subsample determinations. For differential red blood cell counts, triplicate blood smears were fixed in methanol for $\mathrm{ca} 20 \mathrm{~min}$, stained with combined May-Grunwald-Giemsa stain (Culling 1974) and examined under oil immersion on a Leitz photomicroscope. The results were recorded as the mean percentage of 3 counts and were expressed as the percentage of mature, immature, reticulocytic and pyknotic cells in a total count of 300 .

Blood was immediately centrifuged at $1500 \mathrm{rpm}$ $(500 \times$ g) for $5 \mathrm{~min}$ (ambient field temperature) at the low speed setting on a portable MSE Micro Centau Centrifuge. Plasma was then removed from the packed cells and stored at $4{ }^{\circ} \mathrm{C}$ prior to immediate analysis or further storage at $-80^{\circ} \mathrm{C}$. Plasma from test salmon was subjected to Sequential Multiple Analysis via Computer (Technicon SMAC II system) by the Department of Chemical Pathology at Aberdeen Royal Infirmary. The SMAC analyses determined plasma concentrations of albumin protein, alkaline phosphatase, glutamate oxaloacetate transaminase (GOT), calcium, bicarbonate, creatinine, lactate dehydrogenase (LDH), potassium, sodium, total bilirubin, total cholesterol, total protein, urea and uric acid. The methods for plasma determinations are shown in Table 1.

A probit transformation was used to obtain a fit to the erythrocyte osmotic fragility data and to estimate the concentration of sodium chloride at which $50 \%$ haemolysis was expected. Osmotic fragility data were then statistically contrasted using the $95 \%$ confidence limits from the sodium chloride values corresponding to $50 \%$ haemolysis. Mean erythrocyte volumes were compared by examining the $99 \%$ confidence limits which were calculated from the Coulter results on individual fish. Box-and-whisker plots of the median, quartiles and range for remaining haematological and 

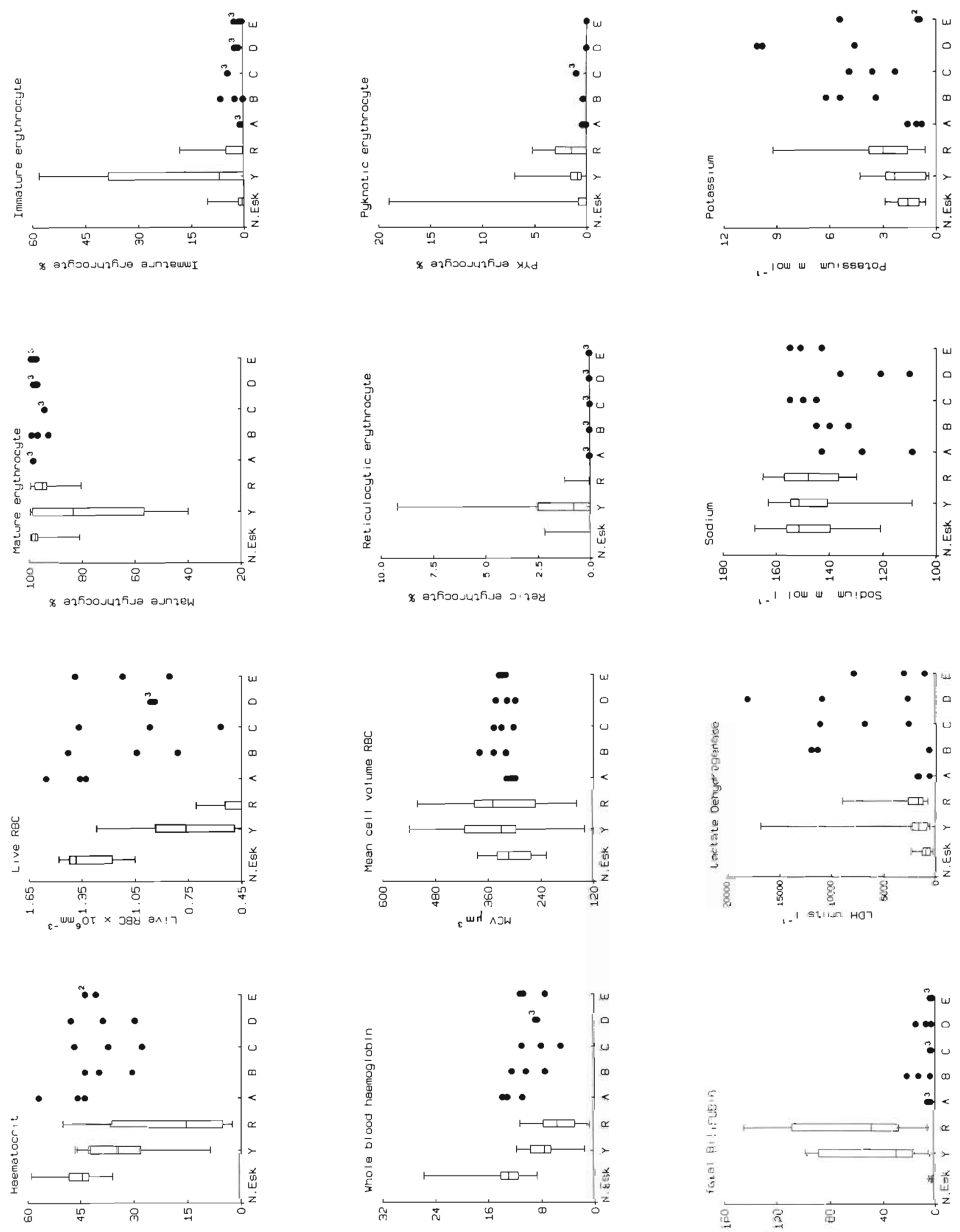

\% ว 1 Jолешаен

.. 106 U!go। 6ошаeH aM

at low 4 uignalig lezol 


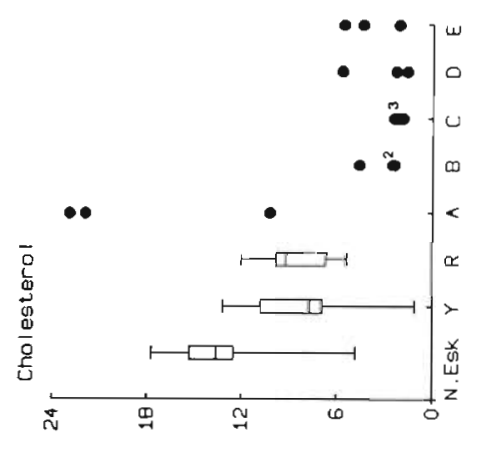

เ- I 10س س 10Ja7sa/OuJ

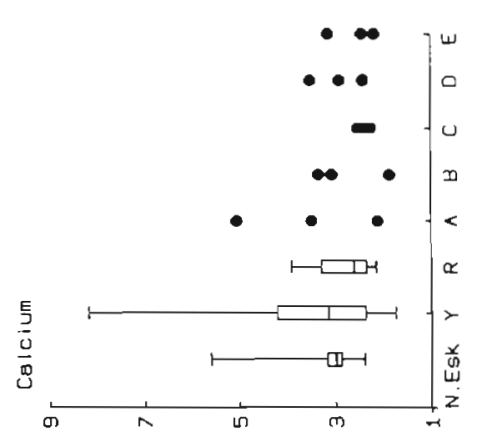

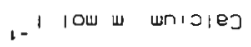
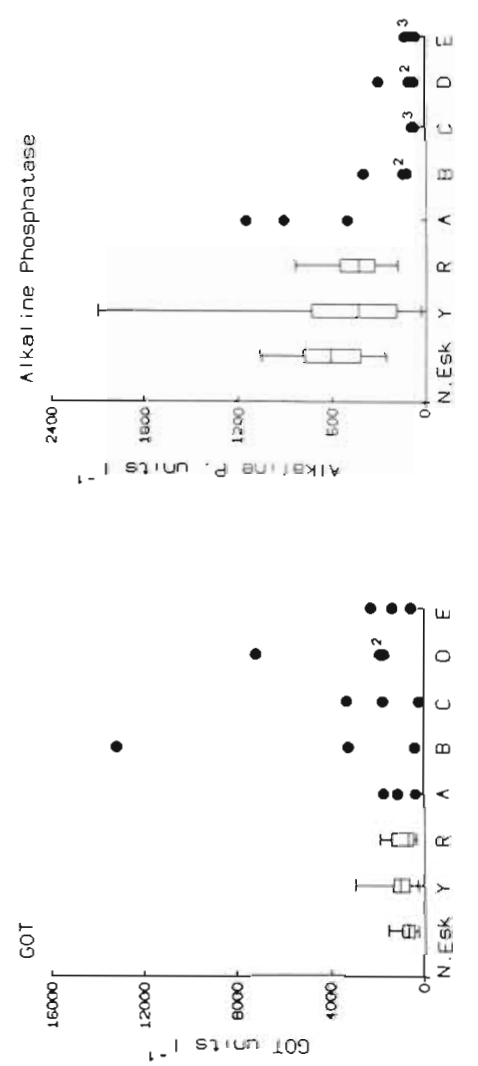

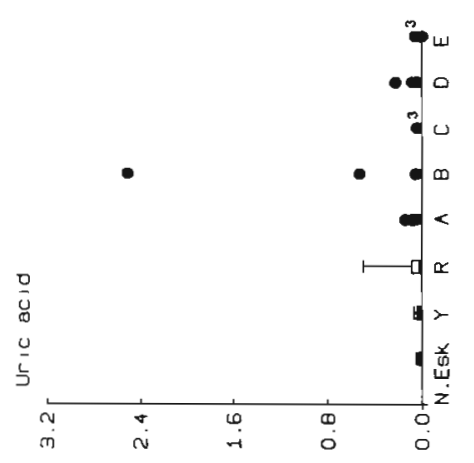

म

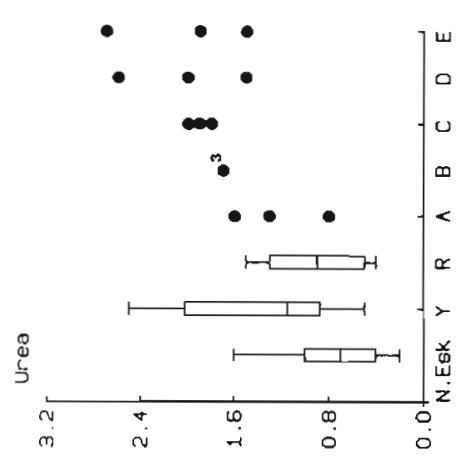

, 1 10س แ อง ก

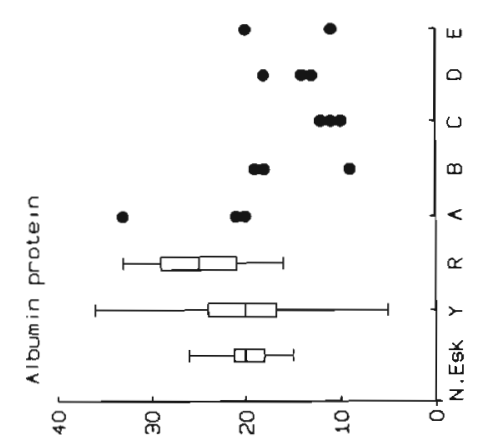

เ- 6 uiazosd u!menalv

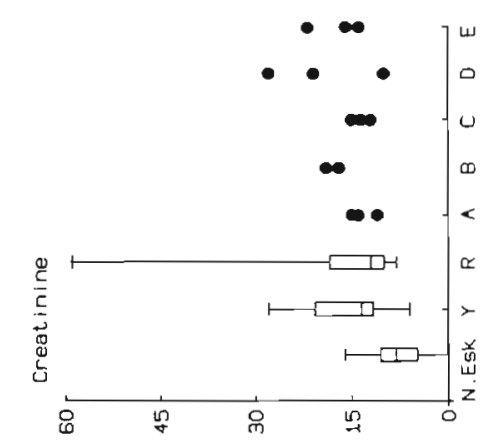

1. 1 iom $A$ anivizeonj
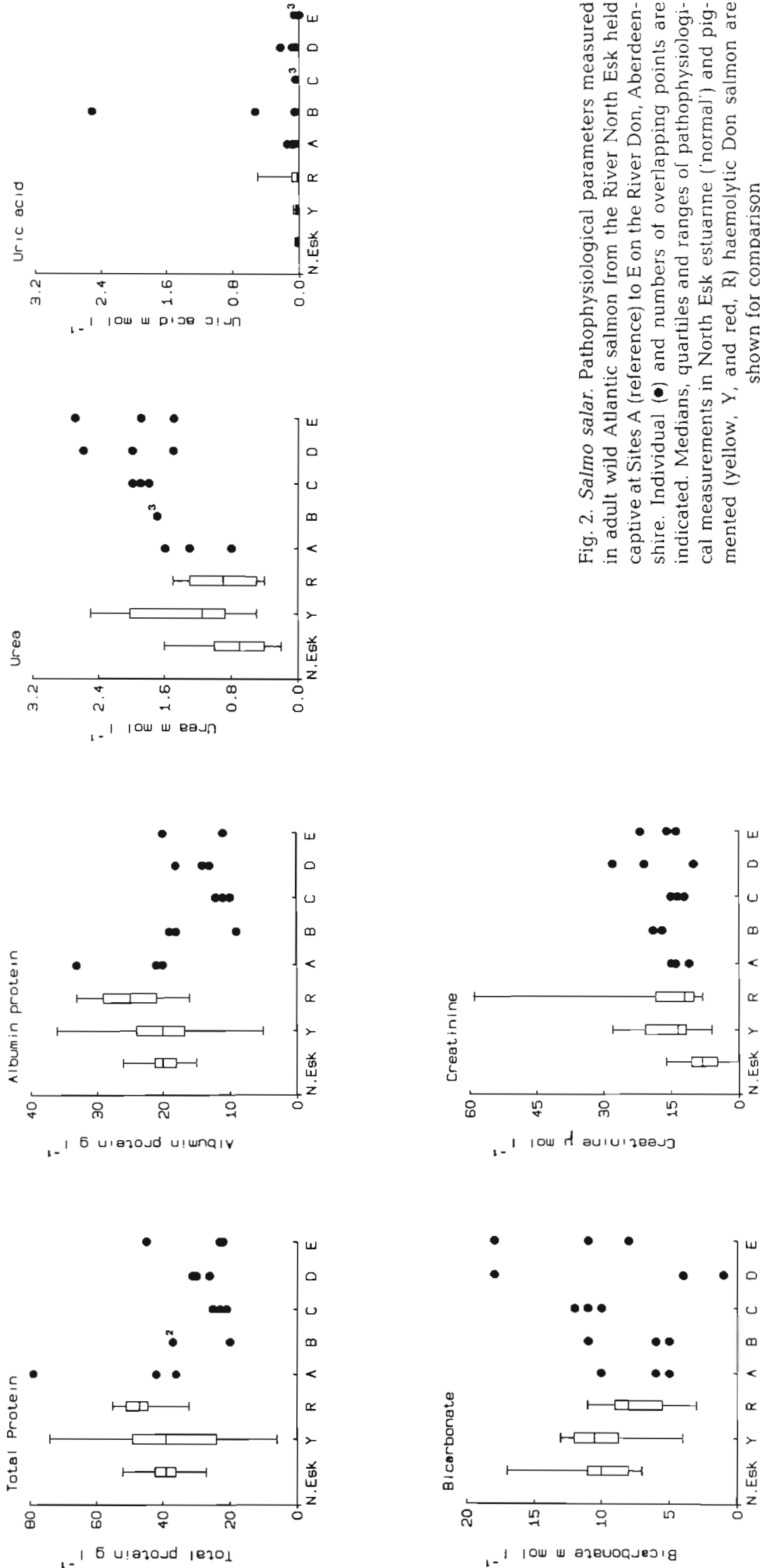
Table 1. Methods used for biochemical examination of Atlantic salmon plasma

\begin{tabular}{|c|c|c|c|}
\hline Parameter & Method of analysis ${ }^{d}$ & Coefficient of variation $(\%)$ & Sensitivity \\
\hline Albumen & $\begin{array}{l}\text { Colourimetric with Bromocresol } \\
\text { green at } 630 \mathrm{~nm}\end{array}$ & 2 & $30-60 \mathrm{gl}^{-1}$ \\
\hline Alkaline phosphatase & $\begin{array}{l}\text { Colourimetric with p-nitro- } \\
\text { phenyl phosphate at } 410 \mathrm{~nm}\end{array}$ & 6 & $0-700$ units $1^{-1}$ \\
\hline Calcium & $\begin{array}{l}\text { Colourimetric with a cresolph- } \\
\text { thalein ion complex at } 570 \mathrm{~nm}\end{array}$ & 3 & $1-3.5 \mathrm{mmol} \mathrm{l}^{-1}$ \\
\hline Carbonate & $\begin{array}{l}\text { Colourimetric with phenolph- } \\
\text { thalein at } 550 \mathrm{~nm}\end{array}$ & 3.5 & $0-40 \mathrm{mmol} \mathrm{l}^{-1}$ \\
\hline Cholesterol $^{ð}$ & $\begin{array}{l}\text { Enzymatic and colourimetric. } \\
\mathrm{H}_{2} \mathrm{O}_{2} \text { production measured with } \\
4 \text {-amino antipyrine at } 510 \mathrm{~nm}\end{array}$ & 2.5 & $0-13 \mathrm{mmol} \mathrm{l}^{-1}$ \\
\hline Creatinine & $\begin{array}{l}\text { Colourimetric with alkaline } \\
\text { picrate at } 505 \mathrm{~nm}\end{array}$ & 4 & $50-100 \mu \mathrm{mol} \mathrm{l}{ }^{-1}$ \\
\hline $\begin{array}{l}\text { Glutamate oxaloacetate trans- } \\
\text { aminase }(G O T)^{b}\end{array}$ & Colourimetric at $340 \mathrm{~nm}$ & 5 & $0-500$ units $^{-1}$ \\
\hline Lactate dehydrogenase $(\mathrm{LDH})^{\mathrm{b}}$ & $\begin{array}{l}\text { Colourimetric (lactate-pyruvate) } \\
\text { at } 340 \mathrm{~nm}\end{array}$ & 5 & $0-600$ units $l^{-1}$ \\
\hline Sodium and potassium & Indirect ion-selective electrodes & $\begin{array}{l}1 \\
2\end{array}$ & $\begin{array}{l}80-160 \mathrm{mmol} \mathrm{l}^{-1} \\
2-8 \mathrm{mmol} \mathrm{l}^{-1}\end{array}$ \\
\hline Total bilirubin & $\begin{array}{l}\text { Colourimetric with Diazo- } \\
\text { sulphanilic acid and caffeine at } \\
600 \mathrm{~nm}\end{array}$ & 3 & $0-350 \mu \mathrm{mol} \mathrm{l}^{-1}$ \\
\hline Total protein & Colourimetric at $550 \mathrm{~nm}$ & 2 & $0-100 \mathrm{gl}^{-1}$ \\
\hline Triglycerides & As for cholesterol (at $500 \mathrm{~nm}$ ) & 2 & $0-5.7 \mathrm{mmol} \mathrm{l}^{-1}$ \\
\hline Urea $^{c}$ & $\begin{array}{l}\text { Colourimetric with diacetyl } \\
\text { monoxime at } 520 \mathrm{~nm}\end{array}$ & $\begin{array}{l}\left.4 \text { (at } 3 \mathrm{mmol} \mathrm{l}^{-1}\right) \\
\left.2 \text { (at } 10 \mathrm{mmol} \mathrm{I}^{-1}\right)\end{array}$ & $0-25 \mathrm{mmol} \mathrm{l}^{-1}$ \\
\hline Uric acid & $\begin{array}{l}\text { Colourimetric with phospho- } \\
\text { tungstate at } 660 \mathrm{~nm}\end{array}$ & 3 & $0-0.9 \mathrm{mmol} \mathrm{l}^{-1}$ \\
\hline
\end{tabular}

pathophysiological values showed a positively skewed distribution. A similar result was obtained for these parameters when measured in the wild adult Atlantic salmon coloured red (R) and yellow ( $Y$ ) from the River Don (Groman \& Miller 1987). Median blood and plasma values for North Esk estuarine, North Esk salmon held captive at Sites $A$ to $E$ and coloured Don fish were statistically compared using the Kruskal-Wallis 1-way analysis of ranks.

\section{RESULTS}

Haematological measurements from adult wild Atlantic salmon from the North Esk estuary (North Esk), North Esk fish held captive at Don Sites A to E (A reference, $B, C, D$ and $E$ ) and haemolytic (red, R) or jaundiced (yellow, Y) Don salmon are plotted in Fig. 2. Don salmon showing clinical signs of haemolytic anaemia or jaundice were termed 'red' and 'yellow' fish respectively because of their gross external appearance as described in Mitchell (1986) and 'clinical profiles' (Gromann \& Miller 1987). Box-and-whisker plots for estuarine North Esk, red and yellow salmon data produced a non-parametric distribution as shown in Fig. 2. The data are shown as medians, quartiles and ranges for North Esk, yellow and red Don salmon. Individual data points are plotted for captive test salmon at Sites A to E. A Kruskal-Wallis 1-way analysis of ranks was computed for each variate using the 8 data sets incorporated in Fig. 2. The numbers of fish examined from each group included 3 captive North Esk salmon per site, 17 to 30 estuarine North Esk fish and 9 to 14 yellow and red Don salmon. For captive adult salmon at the test field sites, measurements were taken from only 3 fish per site and so care was taken in the interpretation of these results. The significance of the test statistic is given in Table 2 where a Kruskal- 
Table 2. Salmo salar. Significance of Kruskal-Wallis 1-way analysis of ranks for physiological variates between all salmon groups

\begin{tabular}{|c|c|c|c|}
\hline Variate & Significance & Variate & Significance \\
\hline Haematocrit & $\cdots$ & Alkaline phosphatase & $\cdots$ \\
\hline Live red blood cell count & $\cdot$ & Cholesterol & $\cdots$ \\
\hline Whole blood haemoglobin & $\cdots$ & Sodium & NS \\
\hline MCV & $\cdot$ & Potassium & $\cdots$ \\
\hline Mature erythrocyte & NS & Calcium & NS \\
\hline Immature erythrocyte & NS & Total protein & $\cdots$ \\
\hline Retic erythrocyte & $\cdot$ & Albumin protein & $\cdot$ \\
\hline Pyk erythrocyte & $\cdot$ & Bicarbonate & $\cdots$ \\
\hline Total bilirubin & $\cdots$ & Creatinine & $\cdots$ \\
\hline $\mathrm{LDH}$ & $\cdots$ & Urea & . \\
\hline $\mathrm{GOT}$ & $\cdot$ & Uric acid & \\
\hline
\end{tabular}

Wallis 1-way analysis of ranks is reported on each blood parameter for all groups.

The physiological parameters which most strongly differentiated the groups were bilirubin, haemoglobin and cholesterol. Yellow and red salmon from the River Don had the highest median bilirubin levels while clinically normal estuarine North Esk and captive fish at the reference site had the lowest. Captive North Esk salmon at Sites B to $E$ on the River Don lay between these extremes. Conversely, whole blood haemoglobin was lowest in yellow and red salmon but highest in captive reference and estuarine North Esk fish. Captive North Esk salmon at Sites B to E on the River Don exhibited haemoglobin levels between the values for coloured and reference fish. For plasma cholesterol, the highest levels were found in captive reference and estuarine North Esk salmon while fish at Sites B to E had the lowest levels. It was clear from the data that captive North Esk salmon held at Sites B to E on the River Don were suffering from a marked bilirubinaemia in comparison to the subacute pathological condition recorded in coloured Don fish. Some individual salmon held captive at Sites B and D had similar clinical profiles to coloured Don fish but with the exception of gross pigmentation.

In addition to changes in plasma bilirubin, cholesterol and whole blood haemoglobin other marked physiological disturbances were also recorded in captive salmon. Marked reductions in haematocrit, live erythrocyte counts and plasma alkaline phosphatase were apparent in conjunction with increased mean erythrocyte volumes for captive salmon at Sites B to $E$ when compared with reference fish. Similarly captive salmon at Sites B to E exhibited elevated plasma potassium urea, creatinine, LDH, GOT and decreased total protein levels compared with reference fish. The majority of the physiological disturbances in captive salmon at
Sites $B$ to $E$ were as marked as those recorded in coloured fish (see Fig. 2).

The osmotic fragility curves of erythrocytes from test group fish are shown in Fig. 3 and expressed as the

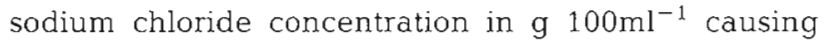
$50 \%$ haemolysis of red blood cells in Table 3 . Individual fish values for erythrocyte osmotic fragilities in

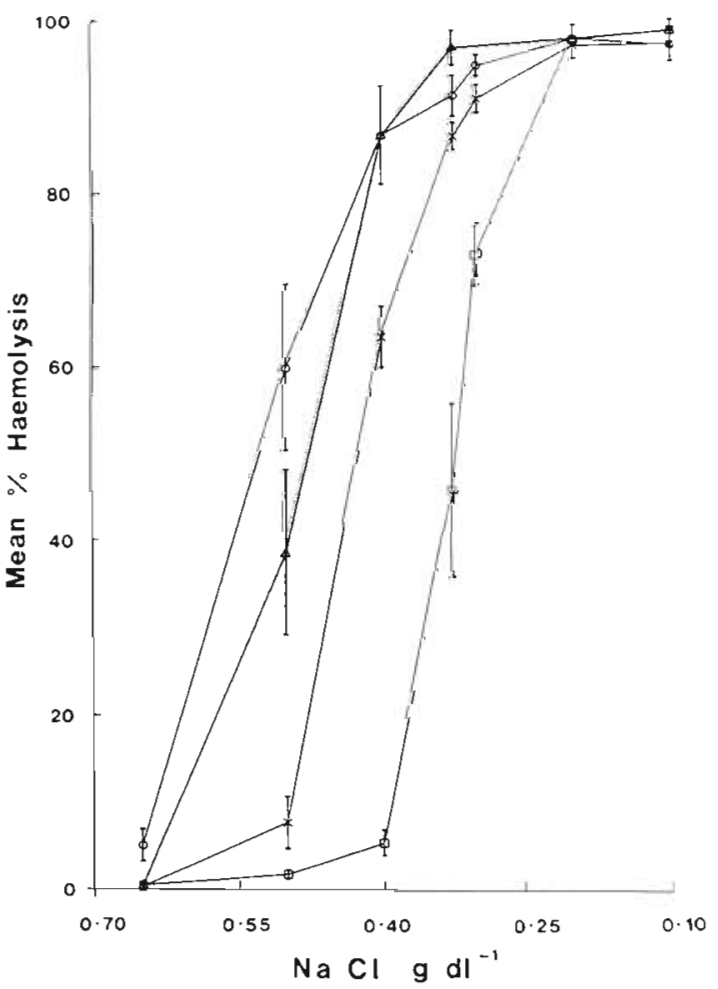

Fig. 3. Salmo salar. Osmotic fragility curves for adult wild Atlantic salmon from the River North Esk estuary $(x)$, reference Site A ( $\square$ ) or pooled Sites B to E (o) on the River (captive North Esk fish), and yellow Don fish $(\Delta)$. Mean values and SE bars are plotted 
Table 3. Salmo salar. Erythrocyte osmotic fragility data for salmon. Erythrocyte osmotic fragilities were judged as significantly $(\mathrm{p}<0.05)$ different between groups by inspecting $95 \%$ confidence limits

\begin{tabular}{|c|c|c|c|}
\hline \multirow[t]{2}{*}{ Salmon group } & \multicolumn{3}{|c|}{ Erythrocyte osmotic fragility } \\
\hline & $\begin{array}{c}\text { Mean } \mathrm{NaCl} \text { conc. (g } 100 \mathrm{ml}^{-1} \text { ) } \\
\text { causing } 50 \% \text { erythrocyte } \\
\text { haemolysis }\end{array}$ & Standard error & $95 \%$ confidence limits \\
\hline $\begin{array}{l}\text { Estuarine }(\mathrm{n}=11) \\
\text { North Esk }\end{array}$ & 0.411 & 0.007 & $0.397-0.425$ \\
\hline $\begin{array}{l}\text { Captive ( } \mathrm{n}=3 \text { ) } \\
\text { Reference site A }\end{array}$ & 0.325 & 0.005 & $0.314-0.336$ \\
\hline $\begin{array}{l}\text { Captive }(n=11) \\
\text { Pooled sites B-E }\end{array}$ & 0.512 & 0.010 & $0.491-0.533$ \\
\hline Yellow Don $(n=3)$ & 0.463 & 0.008 & $0.448-0.478$ \\
\hline
\end{tabular}

captive salmon at Sites B to E were pooled. Data for captive salmon ( $B$ to $E$ ) were contrasted with values for reference fish, estuarine North Esk fish and coloured Don individuals. Inspection of the confidence limits in Table 3 revealed significant $(p<0.05)$ differences in erythrocyte osmotic fragility between estuarine North Esk, captive A and pooled B to E salmon groups. Erythrocyte osmotic fragilities for yellow salmon were associated with values recorded in captive fish held at Sites $B$ to $E$ on the River Don. Unfortunately only a small number of coloured salmon were available for measurement of this additional physiological variable during the field experimental season.

To simplify the conclusions from the Kruskal-Wallis analyses the fish groups were ranked in order of the median value of the variates for which very highly significant differences ( $p<0.001$ ) were found as shown in Table 4. The medians of significantly $(p<0.001)$ changed blood parameters in test groups identified from Table 1 were ranked in ascending or descending order in correspondence with associated physiological disturbances recorded with the pigmented salmon syndrome (Groman \& Miller 1987). Estuarine North Esk and captive riverine North Esk salmon from reference Site $A$ on the River Don produced the lowest overall rankings. Further examination of the physiological variables in Fig. 2 revealed few marked differences between estuarine North Esk and riverine North Esk salmon held at Site A on the River Don. However, the highest rankings associated with major overall physiological disturbances occurred in captive salmon at Sites B to D. The ranking results suggested that the source of the pollutants responsible for the pigmented salmon syndrome lay between Sites A and D. Furthermore, the highest ranking was associated with Site $D$ and suggested that general pollutantrelated physiological disturbances and pathological changes associated with coloured salmon were most marked at this point on the river. The difference between Sites D and E may be attributed to the more localised impact of effluents at Site $D$ compared with Site E further downstream. Furthermore, the water supply for Tank E was abstracted some $500 \mathrm{~m}$ down a paper mill intake lade where reduced water flow may

Table 4. Salmo salar. Simplified ranking of median physiological measurements for which significant differences ( $p<0.001)$ were found. Overall rank was produced by ranking the individual scores for all significant $(p>0.001)$ plasma parameters for each salmon group

\begin{tabular}{|c|c|c|c|c|c|c|c|c|}
\hline & \multicolumn{8}{|c|}{ Rank } \\
\hline & 1 & 2 & 3 & 4 & 5 & 6 & 7 & 8 \\
\hline Haematocrit & $\mathrm{A}$ & N Esk & $E$ & $\mathrm{~B}$ & $\mathrm{D}$ & C & $\mathrm{Y}$ & $\mathrm{R}$ \\
\hline Whole blood haemoglobin & $A$ & N Esk & $E$ & $\mathrm{~B}$ & $\mathrm{D}$ & C & Y & $\mathrm{R}$ \\
\hline Bilirubin & N Esk & $E$ & $\mathrm{C}$ & A & $\mathrm{D}$ & $\mathrm{B}$ & Y & $\mathrm{R}$ \\
\hline $\mathrm{LDH}$ & N Esk & Y & $\mathrm{R}$ & $E$ & A & C & $\mathrm{D}$ & $B$ \\
\hline Alkaline phosphatase & $A$ & N Esk & $\mathrm{R}$ & $\mathrm{Y}$ & $\mathrm{B}$ & $D / E$ & & $\mathrm{C}$ \\
\hline Cholesterol & $A$ & N Esk & $\mathrm{R}$ & Y & $E$ & $\mathrm{~B}$ & $D$ & C \\
\hline Creatinine & N Esk & $R$ & $Y / C$ & & A. & $E$ & $\mathrm{~B}$ & $\mathrm{D}$ \\
\hline Urea & N Esk & $\mathrm{R}$ & $\mathrm{Y}$ & A & $\mathrm{B}$ & $C / E$ & & $\mathrm{D}$ \\
\hline Albumin protein & $\mathrm{R}$ & A & N Esk/Y & $B$ & $\mathrm{D}$ & $\mathrm{C} / \mathrm{E}$ & & \\
\hline Overall & N Esk & A & $\mathrm{R}$ & $\mathrm{Y}$ & $E$ & $B$ & $\mathrm{C}$ & $\mathrm{D}$ \\
\hline
\end{tabular}


have resulted in increased settling of effluent particulate material and increased absorption/adsorption of toxicants by the lade biota. Such conditions may account for the amelioration of pollution effects between Sites D and E. Certainly, with knowledge of the pollutant topography in this area further studies should consider the possibility of additive or synergistic effects of effluents on the River Don at Site D. The highest rankings were not associated with coloured salmon but with Sites B, C and D on the Don. However, nothing is known about the history of effluent exposure for wild Don salmon whereas the fish held in experimental tanks were discretely located for a known period of ca $3 \mathrm{wk}$. Differences in the time and levels of effluent exposure between experimental and wild salmon in the River Don could therefore account for differences in the severity of physiological disturbances.

\section{DISCUSSION}

Physiological disturbances in captive North Esk salmon held at Sites B to D on the River Don indicated the induction of a bilirubinaemia associated with the subacute condition reported in coloured Don fish suffering from a non-infectious hyperbilirubinaemia (Groman \& Miller 1987). During the tests such pathological changes were detectable despite logistic limitations upon the numbers of test fish. It was evident that the source or sources of haemolytic agents lay between the reference site and Site D on the river. Furthermore, the riverine induction of a marked bilirubinaemia in captive salmon occurred when coloured fish were captured from the wild Don stock in the test area of the river.

The major haematological disturbances recorded in captive salmon at Sites B to D and in coloured Don fish were considered to be detrimental since erythrocytes comprise a relatively large proportion of the resting oxygen uptake in fish (Eddy 1975). Further pathological changes were detected in the erythrocytes of salmon from Sites B to D, including elevated red blood cell volumes and osmotic fragilities. Such pathological changes may be precursive to enhanced erythrocyte destruction and reduced red blood cell counts as observed in coloured Don salmon and experimental Esk fish held captive at Sites B to E on the River Don. Erythrocyte osmotic fragilities for estuarine North Esk salmon were very similar to those recorded in either fresh- or seawater adapted rainbow trout (Hughes et al. 1986). However, a further reduction in erythrocyte osmotic fragility was evident in captive North Esk salmon held for 2 to $3 \mathrm{wk}$ at the reference site. The longer recovery time in reference salmon compared to estuarine North Esk fish following capture, handling, anaesthesia and transport prior to bleeding may have ameliorated stress related effects upon the red blood cells. Erythrocyte swelling has been attributed to catecholamine induced changes in red blood cell ultrastructure of stressed fish (Soivio \& Nikinmaa 1981) and may therefore directly affect the osmotic fragility of cells.

Marked elevation of plasma levels in captive salmon at Sites $B$ to $D$ may have been caused by leakage of intracellular potassium through damaged cell membranes into the surrounding body fluids. In North Esk fish held captive on the River Don at Sites B to D and coloured Don fish, ionoregulatory mechanisms appeared incapable of compensating for this physiological disturbance. No significant differences were detected between plasma sodium levels in reference and Site B to E fish. Plasma LDH (lactic dehydrogenase) also showed a marked elevation in captive salmon at Sites B to D compared with the reference fish. LDH belongs to the non-plasma specific enzymes which are located within tissue cells and have no known physiological function in plasma (Tietz 1976). When cell membranes are intact this enzyme is present in the plasma in low concentrations as the cell membranes are impermeable to enzymes when the cells are metabolising normally. Following cell damage the membranes become permeable and enzyme activities are elevated in the extracellular fluid and plasma. Highly elevated levels of plasma LDH may be indicative of the early stages in a haemolytic anaemia Plasma alkaline phosphatase was depressed in salmon at Sites B to E compared with fish from the reference site. Decreased serum levels of alkaline phosphatase have been demonstrated in starved rainbow trout (Sauer \& Haider 1979) and adult wild Atlantic salmon (Johnston et al. 1987). However, the marked difference between fish at Sites $B$ to $E$ and the reference site was associated with enhanced depletion of stored hepatic energy reserves in response to pollutant stress (Scotchford 1988).

Hepatotoxicity was also observed in salmon held at Sites B to E when compared with reference fish. Elevated serum levels of glutamate-oxaloacetate transaminase in captive salmon was indicative of liver and kidney damage (Nemcsók et al. 1981). In the liver of healthy fish transaminases are located in the mitochondria (Nemcsók et al. 1981). Mitochondrial damage has been reported in both wild Don salmon suffering from haemolytic anaemia (Mitchell 1986) and fish held at Sites B to E (Scotchford 1988). Both ultrastructural studies (Mitchell 1986, Scotchford 1988) also report dilation of the rough endoplasmic reticulum in hepatocytes from wild Don and captive fish at Sites B to E. Dilation of the rough endoplasmic reticulum may have resulted from enzymatic hyperfunction and 
appeared to be preceded by necrosis. Enhanced activity of xenobiotic biotransformation enzymes (e.g. $\mathrm{AHH}_{1}$ aryl hydrocarbon hydroxylase, and GST, glutathione-stransferase) has been observed in wild anaemic Don and captive North Esk salmon (Groman et al. 1989) which may explain dilation of the rough endoplasmic reticulum in the hepatocytes of study fish.

Depletion of energy reserves has also been reported with reduced liver lipid and glycogen content in wild coloured and captive salmon from this study (Scotchford 1988). The present study also highighted reduced serum cholesterol in captive salmon at Sites B to $\mathrm{E}$ but not in fish from the reference site. Spawning salmon may show seasonal declines in serum cholesterol levels under non-polluted conditions (Johnston et al. 1987) but riverine exposure to Donside discharges appeared to exacerbate this condition.

Wild Don salmon suffering from haemolytic anaemia also develop an associated jaundice marked by elevated levels of bilirubin in the blood plasma (Groman \& Miller 1987). The jaundiced condition of hyperbilirubinaemia is considered to be a final stage in the process of pollutant intoxication (Everall \& Mitchell 1988). Captive salmon in the present field study exhibited elevated plasma bilirubin levels at Sites B and D. Plasma bilirubin in wild (Groman \& Miller 1987) and captive salmon (George pers. comm. 1989) was present in equal proportions of the conjugated and unconjugated form. Marked haemoglobinaemia and bilirubinaemia in wild Don and captive North Esk salmon at Sites B to D from the River Don exhibited 'clinical profiles' associated with an insult by both haematotoxic and hepatotoxic agents.

Physiological parameters in wild adult Atlantic salmon in the receiving water of the River Don at Sites B to $D$ were strongly affected by effluent discharges in this area. Physiological disturbances in captive salmon were marked and associated with pathological changes observed in coloured Don salmon (Groman \& Miller 1987). Pronounced physiological disturbances in captive salmon at Site $B$ and downstream may be associated with the large discharge (approximately a continuous $80 \mathrm{I} \mathrm{s}^{-1}$ ) of untreated paper mill effluent entering the river below the reference Site A. Indeed many of the haematological disturbances recorded in captive and coloured salmon were similar to those recorded in the literature for the effects of pulp and paper mill effluents on fish (Andersson 1987, Härdig et al. 1988, Scotchford 1988). However, such effluents have not been reported to produce the marked jaundiced or pigmented condition in these studies and plasma bilirubin was found to be present mainly in the conjugated form (Kruzynski 1979, Matsoff \& Oikari 1987 Matsoff \& Nikinmaa 1988). It is possible that other haematotoxic and hepatotoxic agents may be present in Donside effluents below Site B which may further inhibit bilirubin conjugation in the liver and exacerbate the jaundiced condition. Preliminary biological characterisation of individual effluents has indicated that a combination of non-ubiquitous effluent exposures may be capable of producing the pigmented salmon syndrome (Everall \& Mitchell 1988). Sexually mature, nonfeeding and migrating adult wild Atlantic salmon have also been reported to undergo a generalised cachexia in fresh water (Groman et al. 1989). A metabolically altered hepato biliary function in spawning salmon may further inhibit recovery from bilirubinaemia following a toxic insult. The physiological status of adult wild Atlantic salmon during fresh water captivity may therefore help to explain why the pigmented syndrome has not been reported in other indigenous fish stocks in the River Don

Based upon the results of the present studies further field/laboratory biological and chemical characterisation of individual and combined discharges between Sites $A$ and D are now in progress. The aim of further studies is to determine the specific raw effluent(s) and individual chemical(s) responsible for the pigmented syndrome observed in wild adult Atlantic salmon from the River Don, Aberdeenshire

Acknowledgements. The authors thank staff at the DAFS Marine Laboratory in Aberdeen; in particular: Miss A. M. Shanks, for statisticaj analysis; Drs A. E. Ellis, A. L. S. Munro and A. H. McVicar for comments on the manuscript; and the Director, Professor A. D. Hawkins, for providing facilities. We also express our gratitude to Drs $S$ George and $M$ Lever at Stirling University for analyses of xenobiotic detoxification enzymes from the livers of test fish.

\section{LITERATURE CITED}

Andersson, T. (1987). Sublethal physiological effects of pulp and paper mill effluents on fish. A literature review. National Swedish Environmental Protection Board. US Department of Commerce, National Technical Information Service, $54 \mathrm{pp}$.

Blaxhall, P. C., Daisley, K. W (1973). Routine haematological methods for use with fish blood. J. Fish Biol. 5: 771-781

Culling, C. F. A. (1974). Handbook of histopathological and histochemical techniques, 3rd edn. Butterworths, London

Eddy, F. B. (1975). Oxygen uptake by rainbow trout blood, Salmo gairdneri. J. Fish Biol. 10: 87-90

Everall, N. C., Mitchell, C. C. (1988). An epidemiological and toxicological study of haemolytic anaemia affecting wild Atlantic salmon in the River Don, Aberdeenshire, Scotland. North East River Purification Board, Aberdeen, Scotland, $104 \mathrm{pp}$

Gay, J., Jeffcoate, R., Dunn, P. J., Hawkins, J. E. (1987). Stormwater contamination at airports and remedial options - with particular reference to Stansted. J. Inst. Wat. Environ. Manage. 1. 253-262

Groman, D. B., Miller, K. (1987). Haemolytic anaemia of wild Atlantic salmon: haematology and chemical pathology. Aquaculture 67: 210-211 
Groman, D. B., Mitchell, C. G., Miller, K. (1989). An epidemiological study of haemolytic anaemia affecting wild Atlantic salmon in the River Don, Aberdeenshire, Scotland. Interim project completion report 1984-1987. North East River Purification Board, Aberdeen, Scotland. $215 p p$

Härdig, J., Andersson, T., Bengtsson, B., Forlin, L., Larsson, A. (1988). Long-term effects of bleached kraft mill effluents on red and white blood cell status, ion balance and vertebral structure in fish. Ecotoxicol. Environ. Saf. 15: 96-106

Hughes, G. M., Martinez, I. (1986). Comparison of the osmotic fragility of red blood cells in samples of anaesthetised and unanaesthetised trout and eel and the effect of varying oxygen levels. Exp. Biol. 46: 59-65

Hughes, G. M., Martinez, I., Boevy, G. (1986). Comparison of osmotic fragility of red blood cells of freshwater-adapted and seawater-adapted rainbow trout, Salmo gairdneri Richardson. J. Fish Biol. 28: 403-406

Johnston, C. E., Gray, R. W., McLennan, A., Paterson, A. (1987). Effects of photoperiod, temperature and diet on the reconditioning response, blood chemistry, and gonad maturation of Atlantic salmon kelts (Salmo salar) held in freshwater. Can. J. Fish. Aquat. Sci. 44: 702-711

Kruzynski, G. M. (1979). Some effects of dehydroabietic acid (DHAA) on hydromineral balance and other physiological parameters in juvenile sockeye salmon, Oncorhynchus nerka. Ph.D. thesis, Faculty of Graduate Studies, University of British Columbia

Mattsoff, L., Oikari, A. (1987). Acute hyperbilirubinaemia in

Responsible Subject Editor: C. Peters, Hamburg, Germany rainbow trout (Salmo gairdneri) caused by resin acids. Comp. Biochem. Physiol. 88C: 263-268

Mattsoff, L., Nikinmaa, M. (1988). Dehydroabietic acid (DHAA) does not inhibit bilirubin conjugation in the liver of rainbow trout. Bull. environ. Contam. Toxicol. 41: 894-901

Mitchell, C. G. (1986). The histopathology of the haemolytic anaemia syndrome affecting Atlantic salmon (Salmo salar L.) in the River Don. M.Sc. thesis, Plymouth Polytechnic

Nemcsók, J., Benedeczky, I., Boross, L., Aoztalos, B., Orbán, L. (1981). Subcellular localisation of transaminase enzymes in fishes and their significance in the detection of water pollution. Acta Biologica Szegad 27: 9-15

Sauer, D. M., Haider, G. (1979). Enzyme activities in the plasma of rainbow trout, Salmo gairdneri Richardson; the effects of nutritional status and salinity. J. Fish Biol. 14: $407-412$

Scotchford, C. A. (1988). A histological investigation of the liver and red blood cells of Atlantic salmon (Salmo salar Linneaus), affected by a pollutant induced haemolytic anaemia in the River Don. M.Sc. thesis, Plymouth Polytechnic

Soivio, A., Nikinmaa, M. (1981). The swelling of erythrocytes in relation to the oxygen affinity of the blood of rainbow trout, Salmo gairdneri Richardson. In: Pickering, A. D. (ed.) Stress in fish. Academic Press, London, p. $103-119$

Tietz, N. (ed.). (1976). Fundamentals of clinical chemistry. W. B. Saunders, London

Manuscript first received: September 27, 1989

Revised version accepted: January 22, 1991 